\title{
LINGKUNGAN DALAM PERSFEKTIF HADIS
}

\author{
Oleh: Hasri
}

Fakultas Tarbiyah \& IImu Keguruan IAIN Palopo

\begin{abstract}
Abstrak
Konseptualisasi lingkungan atau alam dalam Islam merupakan pemahaman rasional terhadap ayat-ayat kauniyah yang terbentang di hadapan manusia, di samping ayat-ayat qauliyah yang cenderung menjelaskan tentang alam dan seluruh isinya.Keberadaan alam dan seluruh benda-benda yang terkandung di dalamnya merupakan suatu kesatuan yang tidak terpisahkan. Secara keseluruhan saling membutuhkan, dan saling melengkapi kekurangannya. Kelangsungan hidup dari setiap unsur kekuatan alam terkait dengan keberadaan hidup kekuatan lain. Kejadian alam dan apa yang di dalamnya saling mendukung sehingga ia disebut alam secara keseluruhan. Alam dan apa-apa yang ada di dalamnya seperti tumbuh-tumbuhan dan binatang termasuk manusia dan benda mati yang ada di sekitarnya, serta kekuatan alam lainnya seperti angin, udara dan iklim hakekatnya adalah bagian dari keberadaan ecologi alam
\end{abstract}

\section{Kata Kunci: Lingkungan, Hadis}

\section{A. Pendahuluan}

Bencana selalu menimbulkan kesedihan, penderitaan, dan kerugian. Semua orang pasti setuju dengan pendapat ini. Di Koran dan televisi di seantero dunia secara khusus Indonesia para korban murung dan putus asa. Aceh menangis dan Yogya pun berduka. Tambah pangandaran Jawa Barat. Semua penuh dengan luka dan derita. Ada yang mengatakan, ini sudah takdir Allah. Mungkin betul. Para ilmuwan pun mengamini karena letak geografis Indonesia memang rawan bencana.

Deskripsi ala Indonesia di atas sekedar untuk menghentakkan kita bahwa sudah sedemikian parahkah alam dan lingkungan ini sehingga tak sayang terhadap penghuninya? Mungkin Tuhan mulai bosan bersahabat dengan kita. Demikian syair lagu yang sering dilantunkan oleh kalangan artis. Lingkungan yang menjadi perbincangan dalam forum ini senada saja maknanya dengan alam. Alam secara jelas disebutkan dalam Al-Qur'an.

Tetapi yang berbeda adalah peristilahan lingkungan hidup secara baku, baik dari aspek ajaran maupun tradisi keilmuan Islam, kedua-duanya tidak terdapat dalam konsep 
yang konkrit. ${ }^{1}$ Namun isyaratnya jelas di dalam al-Qur'an. Konseptualisasi lingkungan atau alam dalam Islam merupakan pemahaman rasional terhadap ayat-ayat kauniyah yang terbentang di hadapan manusia, di samping ayat-ayat qauliyah yang cenderung menjelaskan tentang alam dan seluruh isinya.

Keberadaan alam dan seluruh benda-benda yang terkandung di dalamnya merupakan suatu kesatuan yang tidak terpisahkan. Secara keseluruhan saling membutuhkan, dan saling melengkapi kekurangannya. Kelangsungan hidup dari setiap unsur kekuatan alam terkait dengan keberadaan hidup kekuatan lain. Kejadian alam dan apa yang di dalamnya saling mendukung sehingga ia disebut alam secara keseluruhan. Alam dan apa-apa yang ada di dalamnya seperti tumbuh-tumbuhan dan binatang termasuk manusia dan benda mati yang ada di sekitarnya, serta kekuatan alam lainnya seperti angin, udara dan iklim hakekatnya adalah bagian dari keberadaan ecologi alam. ${ }^{2}$

Masalah lingkungan dikenal dua kata kunci yang sangat erat hubungannya dengan keserasian lingkungan hidup, yaitu ekologi dan ekosistem. Ungkapan ekologi, berasal dari bahasa Yunani, oikos yang berarti rumah tangga dan kata logos yang berarti ilmu. Jadi ekologi dapat diartikan sebagai studi tentang rumah tangga makhluk hidup. IImu pengetahuan yang membicarakan tentang interaksi antara makhluk hidup dan lingkungannya, termasuk benda mati yang ada di sekitarnya. ${ }^{3}$ Sebab di dalam ekologilah dibicarakan adanya struktur dan interaksi antara makhluk hidup dan lingkungannya. Keberadaan makhluk hidup tidak dapat dipisahkan dari makhluk hidup lainnya, interaksi dalam pengertian saling membutuhkan adalah dasar berkembangnya eksistensi makhluk hidup menjadi makhluk yang mempunyai makna dalam kehidupan. ${ }^{4}$

Kehidupan yang mempunyai makna yang sebenarnya merupakan kehidupan yang memiliki nilai kemanfaatan dalam proses berlangsungnya hidup di alam jagad raya ini. Unsur yang terpenting dalam mewujudkan hidup yang bermakna terletak pada seluruh

\footnotetext{
${ }^{1}$ Soerjani $\mathrm{dkk}$, cenderung menyatakan bahwa lingkungan pada hakekatnya adalah keterkaitan antara manusia dengan makhluk lain juga dengan benda mati yang ada di sekitanya. Lihat M. Soerjani dkk, Lingkungan Sumber Daya Alam dan Kependudukan dalam Pembangunan (Jakarta; UI Press, 1987), h.3

2 Fazhlur Rahman, Al-Qur'an Sumber IImu Pengetahuan, alih bahasa M. Arifin (Jakarta: Bina Aksara, 1987), h. 76

${ }^{3}$ Ecologi as the Scientific Study of the Interactions between Organisme and their Environtment, Michael Begon, John L. Herper, Colin R. Townsend, Ecology: Industrials, Populations, Ani Communities (Massachu Setts: Sinaur Associaties, Inc., 1986), P. X. Lihat juga M. Soerjani dkk, op.cit,. h. 21 h.8

4 Bahri Ghazali, Lingkungan Hidup dalam Pemahaman Islam (Jakarta: Pedoman IImu Jaya, 1996),
} 
makhluk hidup yang memiliki fungsi kegunaan, baik atas dirinya maupun sesama makhluk hidup serta alam sekitarnya sebagai tempat makhluk hidup berada, karena pada setiap makhluk hidup ada kekuatan yang membangkitkan yang disebut energi.

Keberadaan matahari sebagai sumber energi sangat dibutuhkan oleh semua makhluk. Tumbuh-tumbuhan membutuhkan sinar matahari sebagai upaya mematangkan makanan yang dibutuhkan dan batang pepohonan mampu mengatasi banjir yang akan membahayakan makhluk hidup yang lain; hewan, tumbuhan termasuk manusia. Pada pokoknya setiap energi yang ada pada semua makhluk hidup saling dibutuhkan oleh sesamanya makhluk hidup yang masing-masing tergantung kepada makhluk hidup yang lainnya.

Atas dasar keterkaitan makhluk yang satu dengan yang lain dalam satu sistem kehidupan ini terbentuk suatu sistem kehidupan yang disebut Ekosistem. ${ }^{5}$ Ciri-ciri adanya ekosistem adalah berlangsungnya pertukaran dan transformasi energi yang sepenuhnya berlangsung di antara berbagai komponen dalam sistem itu sendiri atau dengan sistem lain di luarnya.

Energi pada setiap makhluk hidup dibutuhkan oleh makhluk hidup yang lain yang menyebabkan terjadinya kelangsungan hidup. Dalam Islam saling keterkaitan ini merupakan salah satu tujuan penciptaan Allah swt, sebab Allah menciptakan sesuatu dengan tidak sia-sia (dengan suatu tujuan). ${ }^{6}$

Adanya keterkaitan menyebabkan terjadinya dinamisasi yang lebih mantap, seimbang dan harmonis dalam kawasan lingkungan hidup. Kestabilan dan kedinamisasian dalam lingkungan terletak pada upaya mengelola dan melestarikan komponen lingkungan hidupnya. Kemudian melanjutkannya dengan melihat apa kaitan kemanfaatannya pada populasi lain, pengelolaan dan kelestarian lingkungan hidup erat hubungannya dengan mendudukkan keseluruhan komponen lingkungan hidup secara kodrati. Selain itu, dalam konteks kebangsaan, rentetan perisiwa dan bencana yang melanda negeri ini- sekedar untuk menyebut- tsunami di Aceh dan Nias Sumaera Utara, banjir banding di Sinjai Sulawesi selatan, dan atau tsunami lagi di Pangandaran jawa Barat, perlu muncul di alam

5 Ibid., h, 3 "Ekosistem adalah satuan kehidupan yang terdiri atas suatu komunitas makhluk hidup (dari berbagai jenis) dengan berbagai benda mati yang berinteraksi membentuk suatu sistem".

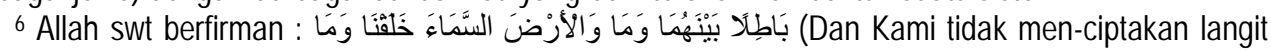
dan bumi dan apa yang ada diantara keduanya dengan sia-sia (tanpa tujuan). (QS. Shad/38 : 27 ) 
kesadaran kita bahwa tidak mesti hanya melimpahkan kepada Tuhan akan penyebabnya. Tetapi perlu koreksi diri, apa yang salah dalam pengelolaan alam dan lingkungan selama ini.Malah yang terakhir, semburan Lumpur Lapindo Brantas di Sidoarjo Jawa Timur semakin menguatkan keyakinan kita bahwa benar firman Allah dalam QS. (30) Rum:41. Inilah per-masalahan yang akan dikaji pada penulisan makalah ini. Tidak saja pada normatifitas al-Qur'an dan hadits sebagai peringatan yang disampaikan sebelumnya tetapi juga pada bukti-bukti nyata bagaimana akibat kaum yang tak peduli akan ajaran al-Qur'an tentang pelestarian alam/lingkungan.

\section{B. Pengertian Pelestarian Lingkungan Hidup}

Kata pelestarian berasal dari kata "lestari" yang berarti tetap seperti keadaan semula, tidak berubah, bertahan kekal. ${ }^{7}$ Kemudian mendapat tambahan pe dan akhiran an, menjadi pelestarian yang berarti; (1) proses, cara, perbuatan melestarikan; (2) perlindungan dari kemusnahan dan kerusa-kan, pengawetan, konservasi; (3) pengelolaan sumber daya alam yang menjamin pemanfaatannya secara bijaksana dannjamin kesinambungan persediaannya dengan tetap memelihara dan meningkatkan kualitas nilai dan keanekaragamannya. ${ }^{8}$ Sedangkan lingkungan hidup berarti; (1) kesatuan ruang dengan semua benda, daya keadaan, dan makhluk hidup, termasuk manusia dan perilakunya yang mempengaruhi perikehidupan dan kesejahteraan manusia serta makhluk hidup lainnya; (2) lingkungan di luar suatu organisme yang terdiri atas organisme hidup, seperti tumbuh-tumbuhan, hewan dan manusia. ${ }^{9}$

Lingkungan hidup tidak saja bersifat fisik seperti tanah, udara, air, cuaca dan sebagainya, namun dapat juga berupa sebagai lingkungan kemis maupun lingkungan sosial. ${ }^{10}$ Lingkungan sosial meliputi antara lain semua faktor atau kondisi di dalam masyarakat yang dapat menimbulkan pengaruh atau perubahan sosiologis, misalnya : ekonomi, politik dan sosial budaya.

7 Departemen Pendidikan Nasional, Kamus Besar Bahasa Indonesia (edisi III; Jakarta: Balai Pustaka, 2001), h. 665

$8 \mathrm{lbid}$.

$9 \mathrm{lbid} .$, h. 675.

10 Slamet Ryadi, Ekologi IImu Lingkungan Dasar-Dasar dan Pengertiannya (Surabaya: Usaha Nasional, 1998), h. 22 
Lingkungan meliputi, yang dinamis (hidup) dan yang statis (mati). Lingkungan dinamis meliputi wilayah manusia, hewan dan tumbuh-tumbuhan. Lingkungan statis meliputi alam yang diciptakan Allah swt, dan industri yang diciptakan manusia. Alam yang diciptakan Allah, meliputi lingkungan bumi, luar angkasa dan langit, matahari, bulan dan tumbuh-tumbuhan. Industri ciptaan manusia, meliputi segala apa yang digali manusia dari sungai-sungai, pohon-pohon yang ditanam, rumah yang dibangun, peralatan yang dibuat, yang dapat menyusut atau membesar, untuk tujuan damai atau perang. ${ }^{11}$

\section{Deskripsi Umum Hadis-Hadis tentang Lingkungan Hidup}

Dalam mengkaji hadis-hadis yang secara khusus membicarakan tentang lingkungan, sebenarnya terdapat banyak kesulitan. Kesulitan pokok adalah tidak adanya term yang jelas tentang lingkungan, misalnya kata yang secara special tentang lingkungan. Beda dengan term lainnya misalnya ilmu, nikah, dan lain-lain yang dengan gampang diakses melalui $C D$ hadis dengan metode takhrij huruf atau tema. Term lingkungan hanya dapat diperoleh dengan membaca keseluruhan matan hadis, menterjemahkan dan mengambil kesimpulan dan menetapkannya sebagai obyek pembahasan. Kata zara'a: menanam misalnya, baru dapat ditetapkan setelah membaca keseluruhan matan hadisnya. ${ }^{12}$

Sebagai pelengkap penulis mencantumkan kata-kata yang terkait fauna, flora, udara, air dan tanah yang terambil dari Al-qur'an dan (mungkin) hadis. Kata- kata dalam hadis sangat susah menghitung jumlah kata yang diinginkan misalnya kata dabbat, karena ketiadaan kamus hadis sebagaimana yang dimiliki al-Qur'an misalnya mu'jam li alfadzil Qur'an.

Term-term yang dapat menjadi dasar pencarian hadis yang berkaitan dengan lingkungan meliputi :

1. Fauna

${ }^{11}$ Mujiono Abdillah, Agama Ramah Lingkungan Perspektif Al-Qur'an (Cet l; Jakarta: Paramadina, 2001), h. $30-31$

12 Muhammad Fuad Abdul Baqi' Al-lu'lui wa al-marjan, juz III (cet I ; Kairo : dar al-hadits, 1997), h. 116. 
Fauna, dalam al-Qur'an ditemukan kata "الأنعام". "الدواب/دan" dan kata pertama berulang sebanyak 18 kali, ${ }^{13}$ sementara yang kedua berulang sebanyak 32 kali. ${ }^{14}$ Dabbah arti dasarnya adalah binatang yang merangkak. Juga diartikan hewan, binatang dan ternak. ${ }^{15}$ Sedangkan al-An'am, arti dasarnya ternak. Ternak disini meliputi: unta, lembu, dan kambing. Mahmud Yunus me-masukkan kerbau. ${ }^{16}$

\section{Flora}

Kata flora dalam kamus bahasa Indonesia, diartikan dengan "segala tumbuhtumbuhan yang terdapat dalam suatu daerah atau di suatu masa". ${ }^{17}$ Istilah ini kemudian dipakai untuk seluruh jenis tumbuhan dan tanaman. Sebagai padanan dari kata flora, dalam al-Qur'an digunakan kata "نبات" dan "الحرث". Yang pertama berulang sebanyak 9 kali, ${ }^{18}$ sementara yang kedua berulang sebanyak 12 kali.19 Nabat berarti tumbuhtumbuhan dan al-harts berarti tanaman.

\section{Tanah, Air dan Udara (Angin)}

Setelah fauna dan flora, maka unsur lingkungan yang sangat vital dalam kehidupan manusia dan makhluk hidup lainnya ialah tanah, air dan udara (angin).

a. Tanah (bumi); dalam bahasa Arab tanah berarti "الأرض". Kata "الأرض" berulang sebanyak 451 kali. $^{20}$

b. Air; kata "ماء" yang berarti air disebut sebanyak 59 kali dalam al-Qur'an. Selain itu "ماؤها ماءكم، ماءها، ماءك،" : 4 bentuk lain, masing-masing disebut satu kali, yaitu: sehingga seluruhnya berjumlah 63 kali. ${ }^{21}$

13 Kata "دابة" berulang sebanyak 14 kali, dan "الدواب" sebanyak 4 kali. Muhammad Fu'ad Abdul Baqi', Mu'jam al-Mufahraz li Alfaz al-Qur'an al-Karim (Indonesia: Maktabah Dahlan, t.th), h. 520-523

14 Kata "الأنعام" berulang sebanyak 26 kali, "انعامام" 2 kali, "انعامهم" 3 kali dan "lbid. h. 879-880. Di samping itu, al-Qur'an juga menyebutkan beberapa jenis binatang yang telah ditentukan sifatnya, misalnya : "الجوارح" "السلع" (binatang buas). Lihat QS. 5: 2), “الصيد" (binatang buruan). Lihat QS. 5: 95, "و القلائد الهدي" : Lihat QS. 5: 2

15 Dari kata "دب يدب، دبا، دبيبا، yang berarti : merangkak, berjalan perlahan-lahan, juga diartikan : merayap. Lihat Mahmud Yunus, Kamus Arab-Indonesia (Jakarta: Hidakarya Agung, 1990), h. 123. M. Quraish Shihab, mengartikan dabbah dengan "yang bergerak". Lihat M. Quraish Shihab, Wawasan Al-Qur'an (Bandung: Mizan, 1996), h. 445

16 Ibid, Mahmud Yunus, h. 459

17 Departemen Pendidikan Nasional, op. cit., h. 278

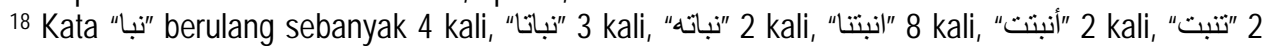
kali, "أنبتكم" 1 kali, "نتبت" 1 kali, "نتبتها" 1 kali, dan "ينبت" 1 kali.

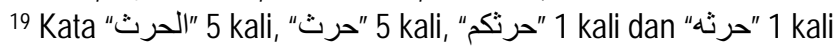

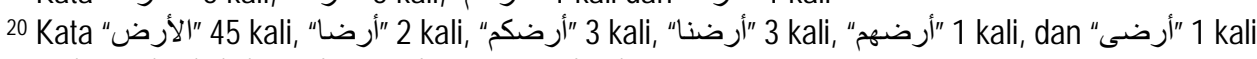

${ }^{21}$ Muhammad Fuad Abdul Baqi', Mu’jam ...op.cit., h. 857 
c. Udara; dalam Kamus Umum Bahasa Indonesia, angin antara lain berarti : (1) gerakan atau aliran udara; (2) hawa, udara. ${ }^{22}$ Dalam al-Qur'an, udara atau angin " الريح،: الرياح", berulang sebanyak 28 kali.23

\section{Hadis-Hadis tentang Lingkungan Hidup}

Islam sebagaimana yang terkandung dalam dalil-dalil normatif seperti Al-qur'an, hadis, kaedah-kaedah fiqih memuat sejumlah aspek dan tujuan perbaikan lingkungan.

1. Pemeliharaan Lingkungan Q.S. Al-A'raf/7: 55

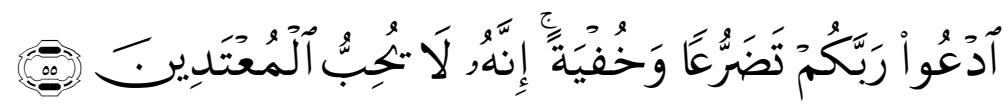

Terjemahnya: Berdoalah kepada Tuhanmu dengan berendah diri dan suara yang lembut. Sesungguhnya Allah tidak menyukai orang-orang yang melampaui batas.

Q.S. Al-Baqarah/2: 2015:

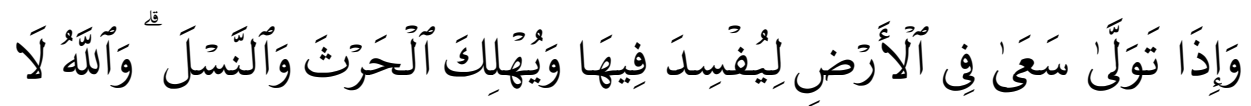

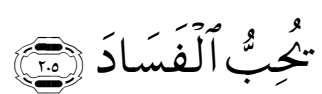

Terjemahnya: Dan apabila ia berpaling (dari kamu), ia berjalan di bumi untuk mengadakan kerusakan padanya, dan merusak tanam-tanaman dan binatang ternak, dan Allah tidak menyukai kebinasaan.

Q.S Ar-Ruum/30:41:

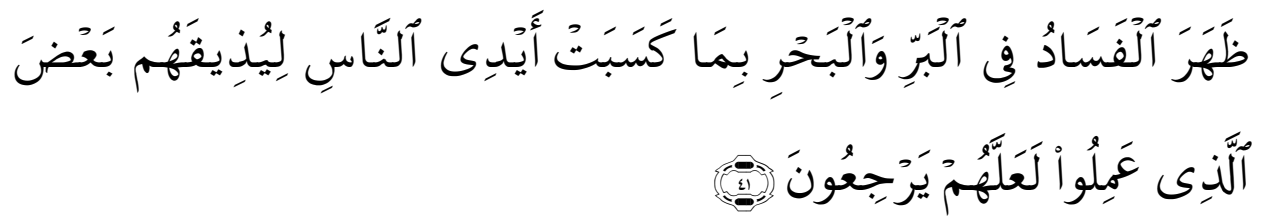

Terjemahnya: Telah nampak kerusakan di darat dan di laut disebabkan Karena perbuatan tangan manusi, supay Allah merasakan kepada mereka sebahagian dari (akibat) perbuatan mereka, agar mereka kembali (ke jalan yang benar).

${ }^{22}$ Departemen Pendidikan Nasional, op. cit., h. 42

${ }^{23}$ Muhammad Fuad Abdul Baqi', Mu'jam... op.cit., h. 414 
2. Pemanfaaan lingkungan

Q.S. Al-Baqarah/2: 22:

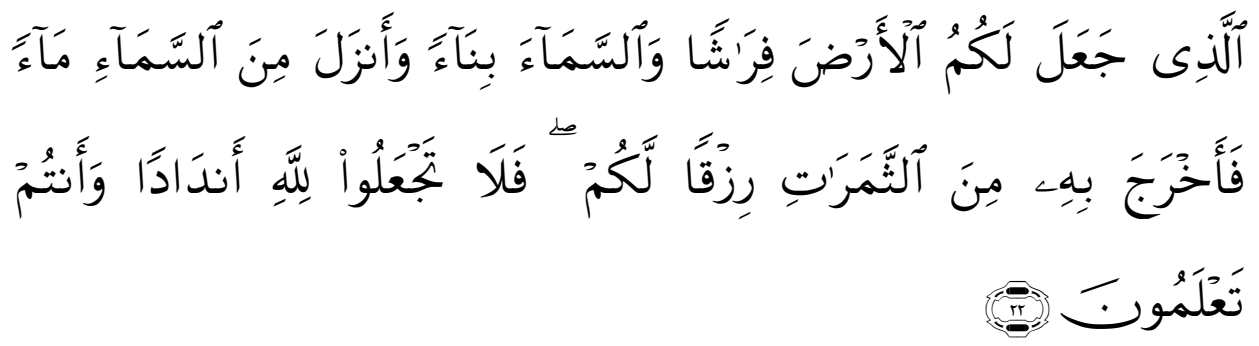

Terjemahnya; Dialah yang menjadikan bumi sebagai hamparan bagimu dan langit sebagai atap, dan dia menurunkan air (hujan) dari langit, lalu dia menghasilkan dengan hujan itu segala buah-buahan sebagai rezki untukmu; Karena itu janganlah kamu mengadakan sekutu-sekutu bagi Allah, padahal kamu Mengetahui.

Q.S. An-Nahl/16:11:

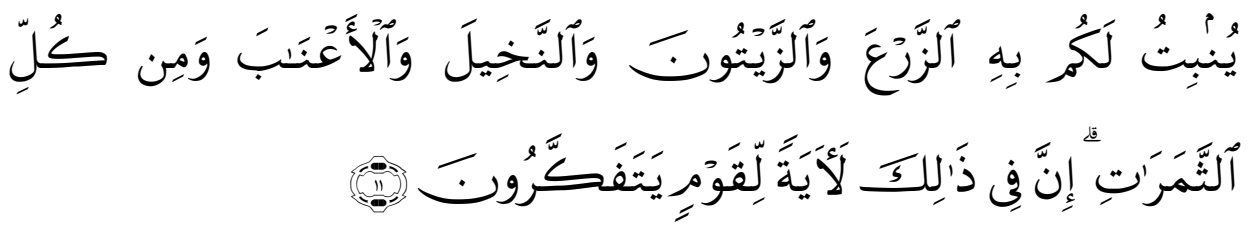

Terjemahnya: Dia menumbuhkan bagi kamu dengan air hujan itu tanamtanaman; zaitun, korma, anggur dan segala macam buah-buahan. Sesungguhnya pada yang demikian itu benar-benar ada tanda (kekuasaan Allah) bagi kaum yang memikirkan.

Q.S. Al-Anbiya/21: 30:

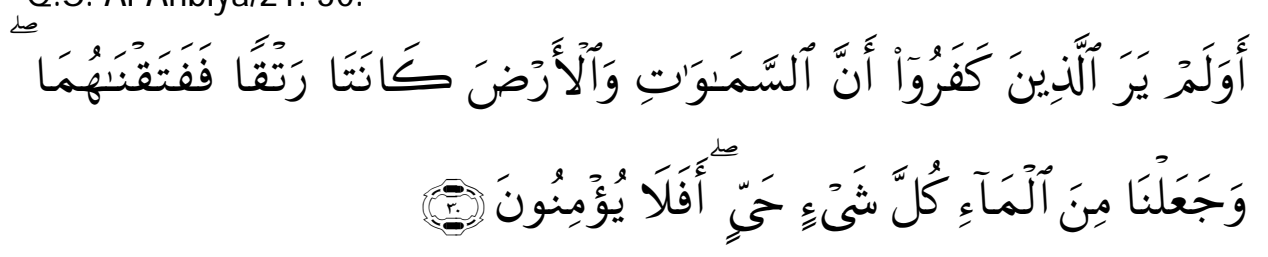

Terjemahnya; Dan apakah orang-orang yang kafir tidak mengetahui bahwasanya langit dan bumi itu keduanya dahulu adalah suatu yang padu, Kemudian kami pisahkan antara keduanya. dan dari air kami jadikan segala sesuatu yang hidup. Maka mengapakah mereka tiada juga beriman? 
3. Pencegahan bencana lingkungan

Q.S. Al-Baqarah/2: 11-12:

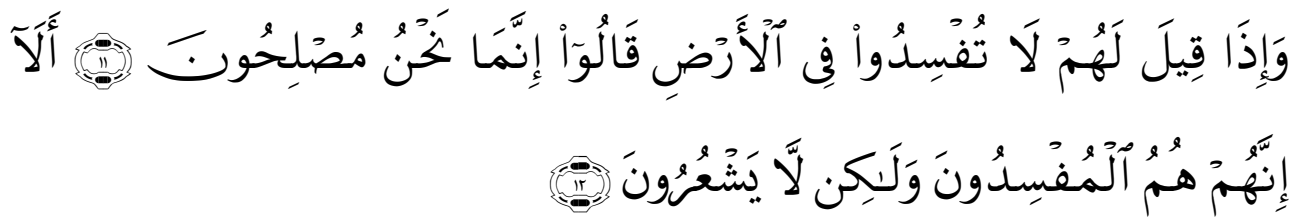

Terjemahnya: Dan bila dikatakan kepada mereka:"Janganlah kamu membuat kerusakan di muka bumi. mereka menjawab: "Sesungguhnya kami orang-orang yang mengadakan perbaikan."

Ingatlah, Sesungguhnya mereka Itulah orang-orang yang membuat kerusakan, tetapi mereka tidak sadar.

Q.S.Ali-Imran/3: 190-191:
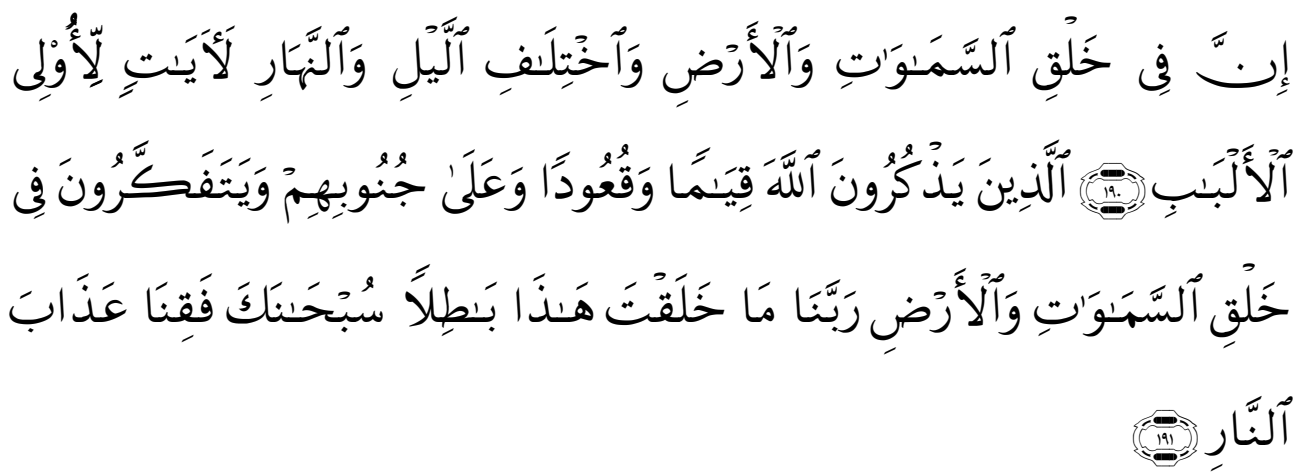

Terjemahnya: Sesungguhnya dalam penciptaan langit dan bumi, dan silih bergantinya malam dan siang terdapat tanda-tanda bagi orang-orang yang berakal. (yaitu) orang-orang yang mengingat Allah sambil berdiri atau duduk atau dalam keadan berbaring dan mereka memikirkan tentang penciptaan langit dan bumi (seraya berkata): "Ya Tuhan kami, tiadalah Engkau menciptakan Ini dengan sia-sia, Maha Suci Engkau, Maka peliharalah kami dari siksa neraka.

Dapat dibayangkan bahwa ketika al-Qur'an diwahyukan kepada Nabi Muhammad Saw, 14 abad yang silam, Dia sudah berbicara tentang daur ulang lingkungan yang sehat lewat angin, gumpalan awan, air, hewan, tumbuh-tumbuhan, proses penyerbukan bunga, buah-buahan yang saling terkait dalam kesatuan ekosistem. Mengingat banyaknya hadis yang berkaitan dengan lingkungan hidup, maka 
pembahasannya pada makalah ini akan dibatasi pada beberapa hadis saja sebagai sampel mengenai pelestarian lingkungan hidup.

\section{Kewajiban Memelihara dan Melindungi Hewan}

Salah satu hadis yang menganjurkan berbuat baik dengan memelihara dan melindungi binatang dengan cara :

a) memberikan makanannya, sebagaimana sabda Rasulullah saw ;

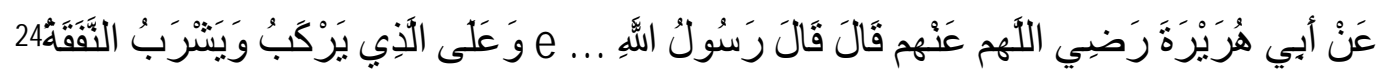

Terjemahnya: Dari Abu Hurairah, berkata: Rasulullah saw bersabda : ...."Orang yang menunggangi dan meminum (susunya) wajib memberinya makanan". (HR. Bukhari)

b) menolongnya, sebagaimana sabda Rasulullah saw :

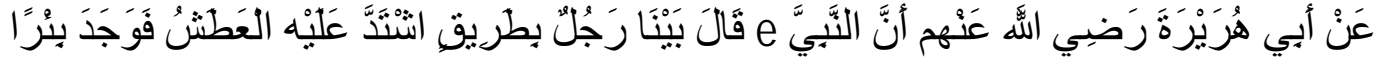

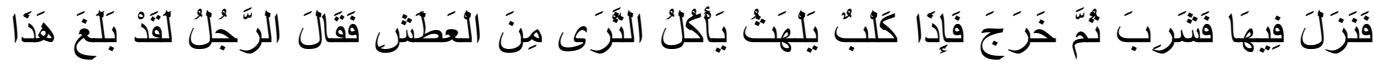

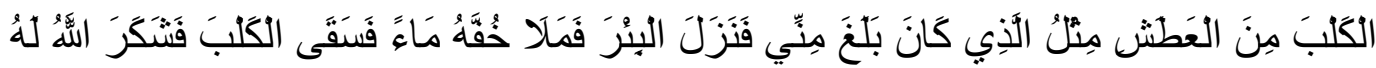

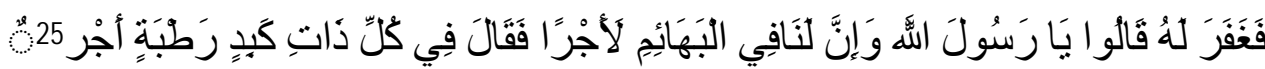

Terjemahnya: Dari Abu Hurairah, berkata; Rasulullah saw bersabda : "suatu ketika seorang laki-laki tengah berjalan di suatu jalanan, tiba-tiba terasa olehnya kehausan yang amat sangat, maka turunlah ia ke dalam suatu sumur lalu minum. Sesudah itu ia keluar dari sumur tiba-tiba ia melihat seekor anjing yang dalam keadaan haus pula sedang menjlat tanah, ketika itu orang tersebut berkata kepada dirinya, demi Allah, anjing ini telah menderita seperti apa yang ia alami. Kemudian ia pun turun ke dalam sumur kemudian mengisikan air ke dalam sepatunya, sepatu itu digigitnya. Setelah ia naik ke atas, ia pun segera memberi minum kepada anjing yang tengah dalam kehausan iu. Lantaran demikian, Tuhan mensyukuri dan mengampuni dosanya. Setelah Nabi saw, menjelaskan hal ini, para sahabat bertanya: "ya Rasulullah, apakah kami memperoleh pahala dalam

${ }^{24}$ Abu Abdullah bin Mughirah bin al-Bardizbat al-Bukhariy, Shahih al-Bukhari, juz II (Bairut: Dar alKutub al-Ilmiyah, 1992), h. 888. Lihat juga al-Syaukani, Nail al-Authar, juz V, h. 353- 354.

25 Ibid., Shahih al-Bukhari, juz II, h. 833; Abu Husain Muslim bin al-Hajjaj, Shahih Muslim, juz IV (Baurut: Dar Ihya al-Turats al-Arabi, t.th), h. 1761. 
memberikan makanan dan minuman kepada hewan-hewan kami ?". Nabi menjawab : "tiap-tiap manfaat yang diberikan kepada hewan hidup, Tuhan memberi pahala". (HR. Bukhari dan Muslim)

Hadis di atas memberikan ketegasan betapa Islam sangat peduli akan keselamatan dan perlindungan hewan. Bahkan disebutkan, bahwa bagi yang menolong hewan sekaligus memperoleh tiga imbalan, yaitu : (1) Allah berterima kasih kepadanya; (2) Allah mengampuni dosa-dosanya; dan (3) Allah memberikan imbalan pahala kepadanya Di samping sebagai Pencipta, Allah adalah penguasa terhadap seluruh makhluk-Nya, termasuk binatang. Dia lah yang memberi rezeki, dan Dia mengetahui tempat berdiam dan tempat penyimpanan makanannya, Allah swt, berfirman dalam QS. Hud (11): 6

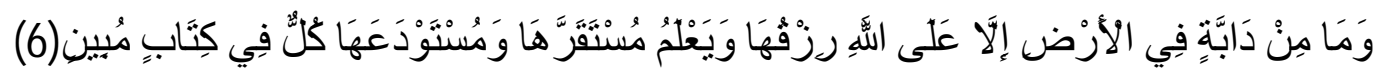

Terjemahnya : Dan tidak ada suatu binatang melatapun di bumi melainkan Allah-lah yang memberi rezkinya, dan Dia mengetahui tempat berdiam binatang itu dan tempat penyimpanannya. Semuanya tertulis dalam kitab yang nyata (Lauh Mahfuzh). ${ }^{26}$

Secara implisit, ayat ini menjelaskan bahwa Allah swt, senantiasa memelihara dan melindungi makhluk-Nya, termasuk binatang dengan cara memberikan makanan dan memotoring tempat tinggalnya. Manusia sebagai makhluk Allah awt, yang termulia diperintahkan untuk selalu berbuat baik dan dilarang untuk berbuat kerusakan di atas bumi, sebagaimana firman-Nya da;a, QS. al-Qashasah (28): 77

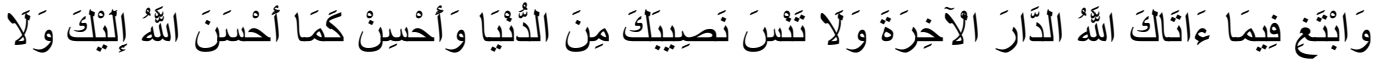

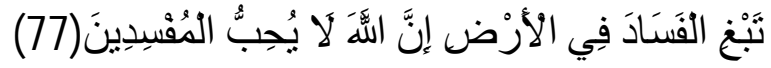

Terjemahnya : Dan carilah pada apa yang telah dianugerahkan Allah kepadamu (kebahagiaan) negeri akhirat, dan janganlah kamu melupakan bahagianmu dari (keni matan) duniawi dan berbuat baiklah (kepada orang lain) sebagaimana Allah telah berbuat baik kepadamu, dan janganlah kamu berbuat kerusakan di (muka) bumi. Sesungguhnya Allah tidak menyukai orang-orang yang berbuat kerusakan. ${ }^{27}$

${ }^{26}$ Departemen Agama RI, Al-Qur'an dan Terjemahnya (Jakarta: Proyek Pengadaan Kitab Suci alQur'an, 1992), h. 327

27 lbid., h. 623 
Di lain ayat, yakni QS. al-A'rāf (7) Allah berfirman :

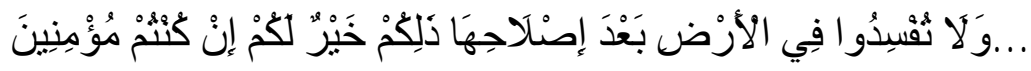
Terjemahnya : ... dan janganlah kamu membuat kerusakan di muka bumi sesudah Tuhan memperbaikinya. Yang demikian itu lebih baik bagimu jika betul-betul kamu orang-orang yang beriman".

Ayat di atas, melarang untuk merusak lingkungan, dan justeru sebaliknya yakni ayat tersebut menganjurkan manusia untuk berbuat baik dan atau memelihara lingkungannya.

\section{Penanaman Pohon dan Penghijauan}

Salah satu konsep pelestarian lingkungan dalam Islam adalah perhatian akan penghijauan dengan cara menanam dan bertani. Nabi Muhammad saw menggolongkan orang-orang yang menanam pohon sebagai shadaqah. Hal ini diungkapkan secara tegas dalam dalam hadits Rasulullah saw, yang berbunyi :

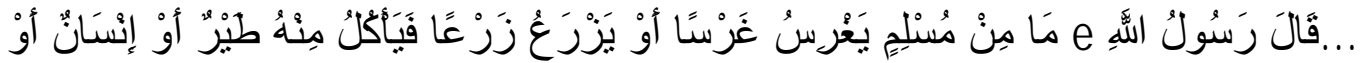

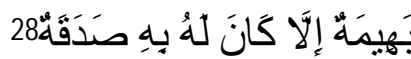

Artinya : ".... Rasulullah saw bersabda : tidaklah seorang muslim menanam tanaman, kemudian tanaman itu dimakan oleh burung, manusia, ataupun hewan, kecuali baginya dengan tanaman itu adalah sadaqah". (HR. al-Bukhari dan Muslim dari Anas).

Pada QS. al-An'am (6): 99, Allah berfirman ;

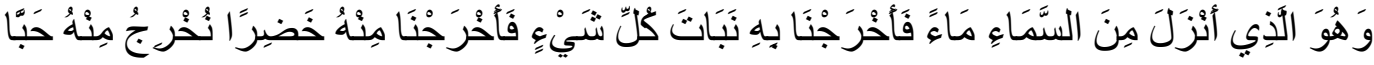

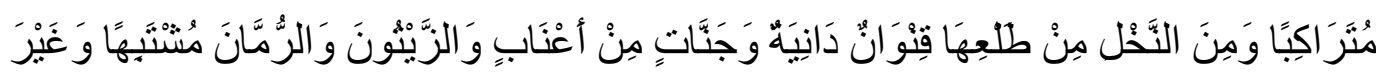

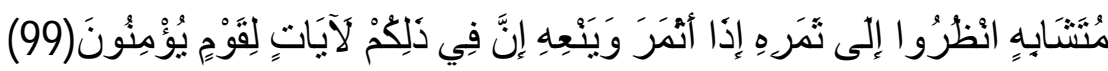

Terjemahnya : Dan Dialah yang menurunkan air hujan dari langit, lalu kami tumbuhkan dengan air itu segala macam tumbuh-tumbuhan, maka Kami keluarkan dari tumbuh-tumbuhan itu tanaman yang menghijau, Kami keluarkan dari tanaman yang 1997), h. 116

28 Lihat Muhammad Fuad Abdul Baqi', Al-Lu'lu wa al-Marjan, juz III (Cet I ; Kairo : Dar al-Hadis, 
menghijau itu butir yang banyak; dan dari mayang kurma mengurai tangkai-tangkai yang menjulai, dan kebun-kebun anggur, dan (Kami keluarkan pula) zaitun dan delima yang serupa dan yang tidak serupa. Perhatikanlah buahnya di waktu pohonnya berbuah, dan (perhatikan pulalah) kematangannya. Sesungguhnya pada yang demikian itu ada tandatanda (kekuasaan Allah) bagi orang-orang yang beriman. ${ }^{29}$

Ada dua pertimbangan mendasar dari upaya penghijauan ini, yaitu :

(a) pertimbangan manfaat, sebagaimana disebutkan dalam QS. Abasa (80): 24-32, sebagai berikut :

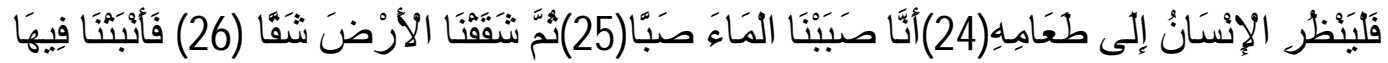

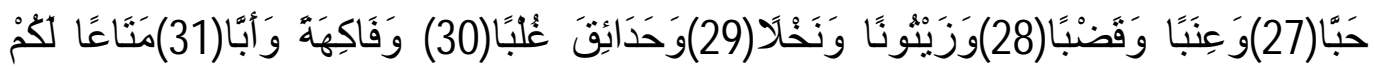

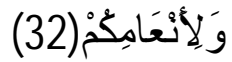

Terjemahnya : maka hendaklah manusia itu memperhatikan makanannya. Sesungguh-nya Kami benar-benar telah mencurahkan air (dari langit), kemudian Kami belah bumi dengan sebaik-baiknya, lalu Kami tumbuhkan biji-bijian di bumi itu, anggur dan sayur-sayuran, Zaitun dan pohon kurma, kebun-kebun (yang) lebat, dan buah-buahan serta rumput-rumputan, untuk kesenanganmu dan untuk binatangbinatang ternakmu. ${ }^{30}$

b) pertimbangan keindahan, sebagaimana disebutkan dalam QS. al-Naml (27): 60, sebagai berikut :

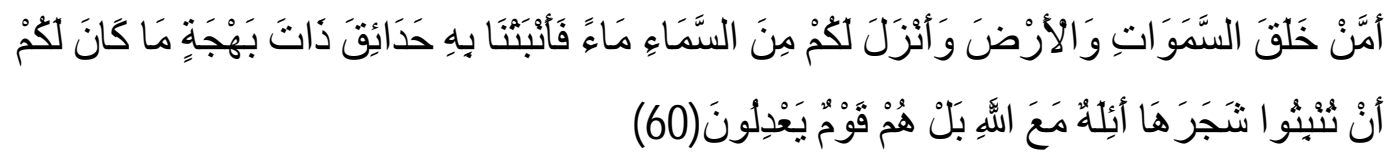

Terjemahnya : Atau siapakah yang telah menciptakan langit dan bumi dan yang menurunkan air untukmu dari langit, lalu Kami tumbuhkan dengan air itu kebunkebun yang berpemandangan indah, yang kamu sekali-kali tidak mampu menumbuhkan pohon-pohonnya? Apakah di samping Allah ada tuhan (yang lain)?

29 Departemen Agama RI, op. cit., h. 203-204

30 Ibid., h. 1025-1026 
Bahkan (sebenarnya) mereka adalah orang-orang yang menyimpang (dari kebenaran). ${ }^{31}$

Maka lihatlah pada ungkapan ini "kebun-kebun yang sangat indah" yang berarti menyejukkan jiwa, mata dan hati ketika memandangnya. Setelah Allah swt, memaparkan nikmat-nikmat-Nya, baik berupa tanaman, kurma, zaitun, buah delima dan semacamnya, Dia melanjutkan firman-Nya وينعه أثمر إذ ثمره إلى أنظروا "lihatlah/perhatikanlah buahnya di waktu pohonnya berbuah, dan (perhatikan pula) kematangannya" (QS. $6: 99$ ).

Imam al-Qurtubi, mengatakan di dalam tafsirnya ; "Bertani bagian dari fardhu kifayah, maka pemerintah harus menganjurkan manusia untuk melakukannya, salah satu bentuk usaha itu adalah dengan menanam pohon."32

\section{Menghidupkan Lahan Mati}

Lahan mati berarti tanah yang tidak bertuan, tidak berair, tidak di isi bangunan dan tidak dimanfaatkan.[33] Allah swt, telah menjelaskan dalam QS. Yasin (36): 33 ;

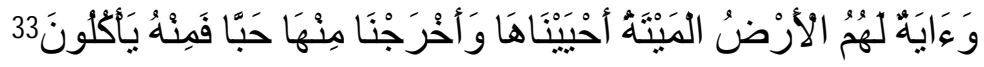

Terjemahnya : Dan suatu tanah (kekuasaan Allah yang besar) bagi mereka adalah bumi yang mati, Kami hidupkan bumi itu dan Kami keluarkan daripadanya biji-bijian, maka dari padanya mereka makan". ${ }^{34}$

Di ayat lain, tepatnya QS. al-Haj (22): 5-6 Allah swt, berfirman :

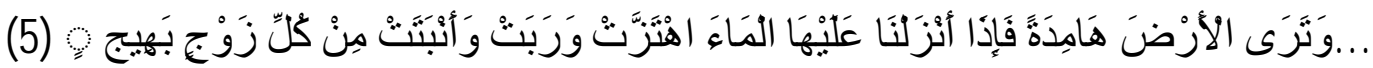

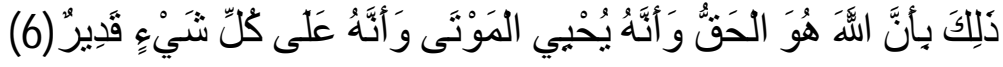

Terjemahnya : ... Dan kamu lihat bumi ini kering, kemudian apabila Kami telah menurunkan air diatasnya, hiduplah bumi itu dan suburlah dan menumbu-hkan berbagai macam tumbuh-tumbuhan yang indah. Yang demikian itu, karena sesungguhnya Allah, Dia lah yang hak dan sesungguhnya Dia lah yang menghidupkan segala yang mati dan sesungguhnya Allah Maha Kuasa atas segala sesuatu. ${ }^{35}$

31 Ibid., h. 601

32 Al-Qurtubi, Tafsir al-Qurtubi (juz III), h. 306

33 Yusuf Qardhawi, op. cit., h, 100

34 Departemen Agama RI, op. cit., h. 709

35 Ibid., h. 512 
Kematian sebuah tanah akan terjadi kalau tanah itu ditinggalkan dan tidak ditanami, tidak ada bangunan serta peradaban, kecuali kalau kemudian tumbuh didalamnya pepohonan. Tanah dikategorikan hidup apabila di dalamnya terdapat air dan pemukiman sebagai tempat tinggal.

Menghidupkan lahan mati adalah ungkapan dalam khazanah keilmuan yang

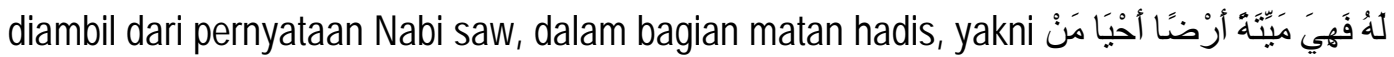
36 (Barang siapa yang menghidupkan tanah (lahan) mati maka ia menjadi miliknya).

Dalam hadis ini Nabi saw, menegaskan bahwa status kepemilikan bagi tanah yang kosong adalah bagi mereka yang menghidupkannya, sebagai motivasi dan anjuran bagi mereka yang menghidupkannya. Menghidupkan lahan mati, usaha ini dikategorikan sebagai suatu keutamaan yang dianjurkan Islam, serta dijanjikan bagi yang mengupayakannya pahala yang amat besar, karena usaha ini adalah dikategorikan sebagai usaha pengembangan pertanian dan menambah sumber-sumber produksi. ${ }^{37}$ Sedangkan bagi siapa saja yang berusaha untuk merusak usaha seperti ini dengan cara menebang pohon akan dicelupkan kepalanya ke dalam neraka. Hal ini sesuai dengan sabda Rasulullah saw sebagaimana dalam bagian matan hadis, yakni ; صَوَّبَ سِدْرَة فَطْعَ مَنْ (Barang siapa yang menebang pepohonan, maka Allah akan mencelupkannya ke dalam neraka).

Maksud hadis di atas, dijelaskan kemudian oleh Abu Daud setelah meriwayatkan hadis tersebut, yaitu kepada orang yang memotong pepohonan secara sia-sia sepanjang jalan, tempat para musafir dan hewan berteduh. Ancaman keras tersebut secara eksplisit merupakan ikhtiar untuk menjaga kelestarian pohon, karena keberadaan pepohonan tersebut banyak memberi manfaat bagi lingkungan sekitar. Kecuali, jika penebangan itu dilakukan dengan pertimbangan cermat atau menanam pepohonan baru dan menyiramnya agar bisa menggantikan fungsi pohon yang ditebang itu.

\section{Udara}

Salah satu kebutuhan pokok manusia adalah udara, dalam hal ini udara yang mengandung oksigen yang diperlukan manusia untuk pernafasan. Tanpa oksigen, manusia tidak dapat hidup.

\footnotetext{
${ }^{36}$ Abu Daud, Sunan Abu Daud, op. cit., (3073)

37 Yusuf Qardhawi, op. cit., h. 101

38 Abu Daud, op. cit., Kitab Adab (5239)
} 
Tuhan beberapa kali menyebut angin (udara) dan fungsinya dalam proses daur air dan hujan. Firman Allah swt dalam QS. al-Baqarah (2): 164

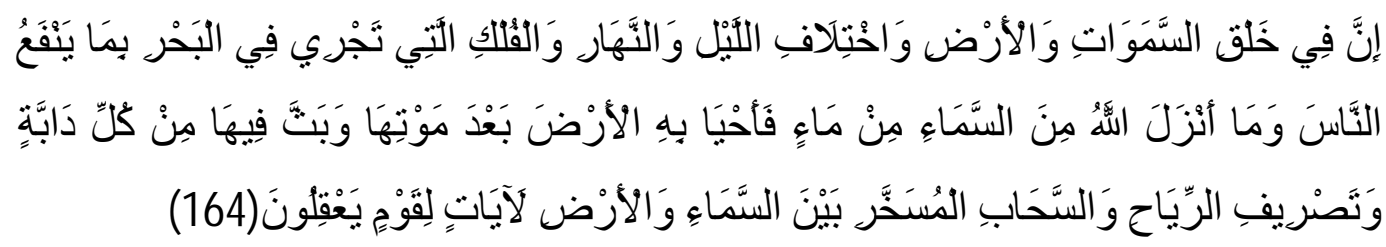

Terjemahnya : Sesungguhnya dalam penciptaan langit dan bumi, silih bergantinya malam dan siang, bahtera yang berlayar di laut membawa apa yang berguna bagi manusia, dan apa yang Allah turunkan dari langit berupa air, lalu dengan air itu Dia hidupkan bumi sesudah mati (kering) -nya dan Dia sebarkan di bumi itu segala jenis hewan, dan pengisaran angin dan awan yang dikendalikan antara langit dan bumi; Sungguh (terdapat) tanda-tanda (keesaan dan kebesaran Allah) bagi kaum yang memikirkan. ${ }^{39}$

Pada ayat lain, yakni QS. al-Rum (30): 48 Allah juga berfirman :

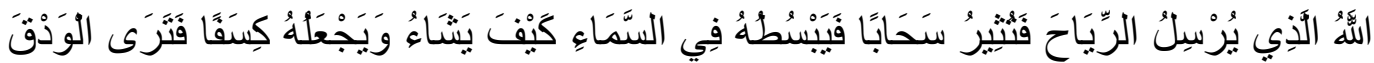

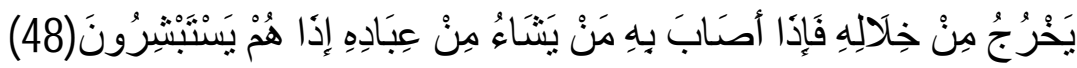

Terjemahnya: Allah, Dialah yang mengirim angin, lalu angin itu menggerakkan awan dan Allah membentangkannya di langit menurut yang dikehendaki-Nya, dan menjadikannya bergumpal-gumpal; lalu kamu lihat hujan ke luar dari celah-celahnya, maka apabila hujan itu turun mengenai hamba-hamba-Nya yang dikehendaki-Nya tiba-tiba mereka menjadi gembira. ${ }^{40}$

Udara merupakan pembauran gas yang mengisi ruang bumi, dan uap air yang meliputinya dari segala penjuru. Udara adalah salah satu dari empat unsur yang seluruh alam bergantung kepadanya. Empat unsur tersebut ialah tanah, air, udara dan api. Dalam perkembangan ilmu pengetahuan modern telah membuktikan bahwa keempat unsur ini bukanlah zat yang sederhana, akan tetapi merupakan persenyawaan dari berbagai macam unsur. 41

\footnotetext{
39 Departemen Agama RI, op. cit., h. 40

40 Ibid., h. 649

41 Yusuf Qardhawi, op.cit., h. 260
} 
Air misalnya, terdiri dari unsur oksigen dan hidrogen. Demikian juga tanah yang terbentuk dari belasan unsur berbeda. Adapun udara, ia terbentuk dari sekian ratus unsur, dengan dua unsur yang paling dominan, yaitu nitrogen 42 yang mencapai sekitar 78,084 persen dan oksigen ${ }^{43}$ sebanyak 20,946 persen. Satu persen sisanya adalah unsur-unsur lain. ${ }^{44}$

Termasuk hikmah kekuasaan Tuhan dalam penciptaan alam ini, bahwa Dia menciptakan udara dengan nitrogen dan sifatnya yang pasif sebagai kandungan mayoritasnya, yaitu 78 persen dari udara. Kalau saja kandungan udara akan gas nitrogen kurang dari itu, niscaya akan berjatuhan bunga-bunga api dari angkasa luar karena mudahnya menembus lapisan bumi (hal itu yang kerap kali terjadi) dan terbakarlah segala sesuatu yang ada pada permukaan bumi. ${ }^{45}$

Fungsi lain dari udara/angin adalah dalam proses penyerbukan/ mengawinkan tumbuh-tumbuhan. Allah swt, berfirman dalam QS. al-Hijr (15): 22 sebagai berikut :

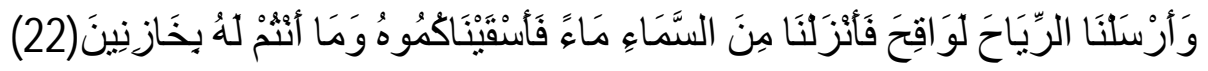

Terjemahnya : Dan Kami telah meniupkan angin untuk mengawinkan (tumbuhtumbuhan) dan Kami turunkan hujan dari langit, lalu kami beri minum kamu dengan air itu, dan sekali-kali bukanlah kamu yang menyimpan-nya. 46

Dengan Di antara sekian banyak manfaat angin adalah kemampuannya dalam menggerakkan kapal-kapal untuk terus berlayar dengan izin Allah. Angin berfungsi juga untuk mengalirkan air dari satu tempat ke tempat lain, dan yang menyebabkan terbaginya hewan-hewan air ke berbagai permukaan air. Dalam kehidupan tumbuh-tumbuhan, anginlah yang membawa benih-benih yang menyebabkan kesuburan dan penyerbukan serta penyebaran tumbuh-tumbuhan ke berbagai belahan bumi. ${ }^{47}$ Namun angin juga bisa menjadi bencana bagi makhluk hidup ketika ia menjadi badai misalnya, Allah telah menghancurkan kaum 'Ad dengan angin badai karena kekafiran dan kesombongan

\footnotetext{
42 Nitrogen adalah gas yang pasif dan mandul. Ibid.

${ }^{43}$ Oksigen adalah gas yang aktif dan sangat penting bagi manusia dan makhluk hidup lainnya. Ibid, h. 261.

44 ibid

45 Lihat ibid, dan bandingkan dengan Muhammad Abdul Qadir Al-Faqqi, Al-Bi'ah ; Masyakiluha wa Qadhayaha, op. cit., h. 52-69.

${ }^{46}$ Departemen Agama RI, op. cit., h. 392

${ }^{47}$ Abdul Majid al-Najjar, Qadhaya Al-Bi'ah min Manzhur Al-Islami, yang disalin dari IImu Bi'ah karya Ulya Hatukh dan Muhammad, Handani, h. 92.
} 
mereka di atas muka bumi ini, lalu mereka berkata, "Siapakah diantara kita yang lebih kuat?". Allah swt, berfirman dalam QS. al-Dzariyat (51): 41-42

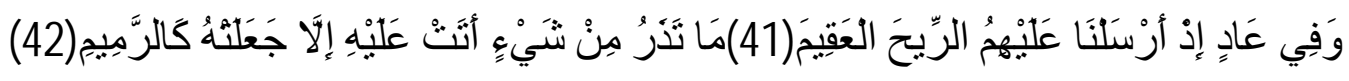

Terjemahnya : Dan juga pada (kisah) 'Ad ketika Kami kirimkan kepada mereka angin yang membinasakan. Angin itu tidak membiarkan satu pun yang dilandanya melainkan dijadikannya seperti serbuk. ${ }^{48}$

Sebagai manusia terkadang muncul ketika datang angin topan yang sangat kencang dengan membawa debu dan hawa panas, yang akan membuat sebagian manusia sakit, mereka lupa bahwa itu semua terjadi atas kehendak Allah dan berjalan sesuai dengan hukum alam Nya yang tidak dapat dirubah. Sebab itulah Nabi saw, melarang pencelaan terhadap angin, beliau bersabda :

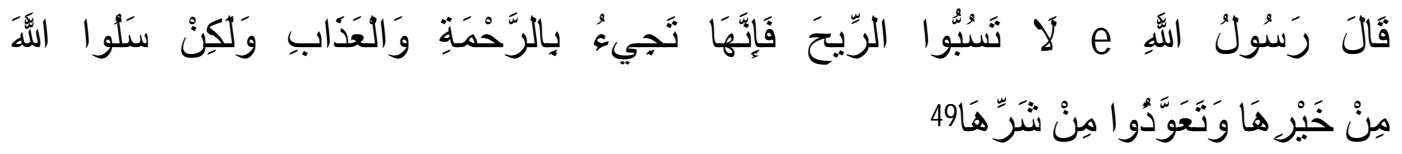

Artinya: Rasulullah saw bersabda : Janganlah kalian mencela angin, karena sesungguhnya ia berasal dari ruh Allah Ta'ala yang datang membawa rahmat dan azab, akan tetapi mohonlah kepada Allah dari kebaikan angin tersebut dan berlindunglah kepada Allah dari kejahatannya. (HR. Ahmad dari Abu Hurairah)

Sungguh, nikmat udara merupakan suatu nikmat yang sangat besar. Dengan demikian, manusia dituntut untuk memanfaatkannya sesuai dengan karunia yang telah dianugerahkan Allah kepada mereka, dengan melestarikannya bukan dengan mencemarinya dan merusaknya, yang akan membawa mudharat bagi dirinya dan makhluk ciptaan Allah Swt, lainnya.

\section{Air}

Sumber kekayaan lain yang sangat penting untuk dijaga adalah air, sumber kehidupan bagi manusia, tumbuh-tumbuhan dan hewan. Allah Swt, berfirman dalam QS.

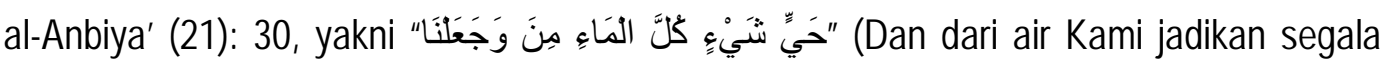
sesuatu hidup).

Pada hakekatnya, air adalah kekayaan yang mahal dan berharga. Akan tetapi karena Allah menyediakannya di laut, sungai bahkan hujan secara gratis, manusia

${ }^{49}$ Ahmad, Musnad Ahmad bin Hanbal (2/268, 409, dan 518). Dan Ibnu Majah, kitab Al-Adab (3727) 
seringkali tidak menghargai air sebagaimana mestinya. Namun satu hal penting yang layak direnungkan, bahwa air bukanlah komoditas yang bisa tumbuh dan berkembang. la tidak sama, misalnya dengan kekayaan nabati atau hewani, sebab itulah Allah swt, mengisyaratkan dalam QS. al-Mu'minun (23): 18

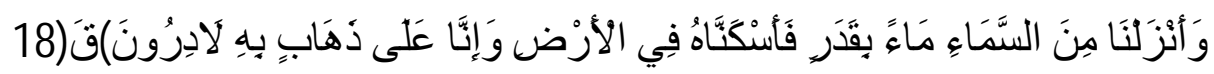
Terjemahnya : Dan Kami turunkan air dari langit menurut suatu ukuran; lalu Kami jadikan air itu menetap di bumi, dan sesungguhnya Kami benar-benar berkuasa menghilangkannya. 50

Jika makhluk hidup terutama manusia tidak bisa hidup tanpa air, sementara kuantitas air terbatas, maka manusia wajib menjaga dan melestarikan kekayaan yang amat berharga ini. Jangan sekali-kali melakukan tindakan-tindakan kontra produktif, yaitu dengan cara mencemarinya, merusak sumbernya dan lain-lain. Termasuk pula dengan tidak menggunakan air secara berlebih-lebihan (israf), menurut ukuran-ukuran yang wajar.

a. Larangan mencemari air

b. Penggunaan air secara berlebihan.

\section{Menghindari Kerusakan dan Menjaga Keseimbangan Alam.}

Salah satu tuntunan terpenting Islam dalam hubungannya dengan lingkungan, ialah bagaimana menjaga keseimbangan alam/ lingkungan dan habitat yang ada tanpa merusaknya. Karena tidak diragukan lagi bahwa Allah menciptakan segala sesuatu di alam ini dengan perhitungan tertentu. Seperti dalam firman Nya dalam QS. al-Mulk (67): 3

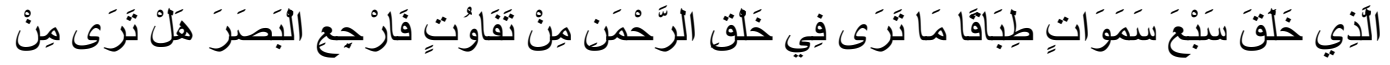
فُطور)(3)

Terjemahnya : Allah yang telah menciptakan tujuh langit berlapis-lapis. Kamu sekalikali tidak melihat pada ciptaan Tuhan yang Maha Pemurah sesuatu yang tidak

50 Departemen Agama RI, op. cit., h. 528 
seimbang. Maka lihatlah berulang-ulang. Adakah kamu lihat sesuatu yang tidak seimbang. ${ }^{51}$

Inilah prinsip yang senantiasa diharapkan dari manusia, yakni sikap adil dan moderat dalam konteks keseimbangan lingkungan, tidak hiperbolis atau pun meremehkan, sebab ketika manusia sudah bersikap hiperbolis atau meremehkan, ia cenderung menyimpang, lalai serta merusak. Hiperbolis di sini maksudnya adalah berlebih-lebihan dan melewati batas kewajaran. Sementara meremehkan maksudnya ialah lalai serta mengecilkan makna yang ada. ${ }^{52}$ Keduanya merupakan sikap yang tercela, sedangkan sikap adil dan moderat adalah sikap terpuji.

Sikap adil, moderat, ditengah-tengah dan seimbang seperti inilah yang diharapkan dari manusia dalam menyikapi setiap persoalan. Baik itu berbentuk materi maupun inmateri, persoalan-persoalan lingkungan dan persoalan umat manusia, serta persoalan hidup seluruhnya.

Keseimbangan yang diciptakan Allah swt, dalam suatu lingkungan hidup akan terus berlangsung dan baru akan terganggu jika terjadi suatu keadaan luar biasa, seperti gempa tektonik, gempa yang disebabkan terjadinya pergeseran kerak bumi.53 Tetapi menurut al-Qur'an, kebanyakan bencana di planet bumi disebabkan oleh ulah perbuatan manusia yang tidak bertanggung jawab. Firman Allah swt yang menandaskan hal tersebut adalah QS. al-Rum (30): 41, sebagai berikut :

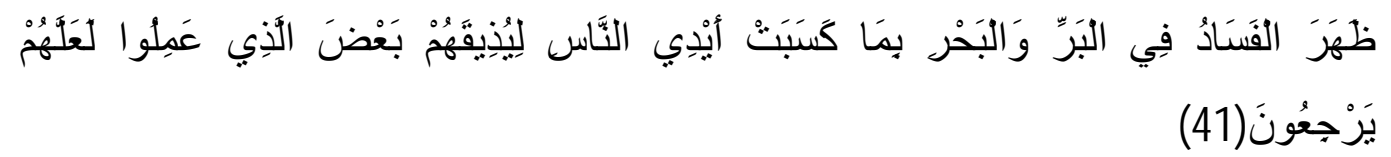

Terjemahnya: Telah nampak kerusakan di darat dan di laut disebabkan karena perbuatan tangan manusia supaya Allah merasakan kepada mereka sebahagian dari (akibat) perbuatan mereka, agar mereka kembali (kejalan yang benar)". ${ }^{54}$

Selanjutnya Allah awt, berfirman di dalam QS. Ali Imran (3): 182

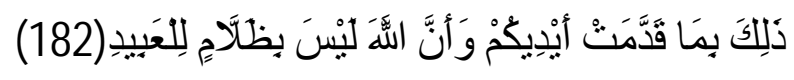

51 Departemen Agama RI, op. cit., h. 955

52 Yusuf Qardhawi, op.cit., h.235

${ }^{53}$ M. Amin Abdullah, op.cit., h. 183

54 Departemen Agama RI, op. cit., h. 647 
Terjemahnya : (Adzab) yang demikian itu adalah disebabkan perbuatan tanganmu sendiri, dan bahwasanya Allah sekali-kali tidak menganiaya hamba Nya. ${ }^{55}$

Di abad ini, campur tangan umat manusia terhadap lingkungan cenderung meningkat dan terlihat semakin meningkat lagi terutama pada beberapa dasawarsa terakhir. Tindakan-tindakan mereka tersebut merusak keseimbangan lingkungan serta keseimbangan interaksi antar elemen-elemennya. Terkadang karena terlalu berlebihan, dan terkadang pula karena terlalu meremehkan. Semua itu menyebabkan penggundulan hutan di berbagai tempat, pendangkalan laut, gangguan terhadap habitat secara global, meningkatnya suhu udara, serta menipisnya lapisan ozon yang sangat mencemaskan umat manusia dalam waktu dekat.

Demikianlah, kecemasan yang melanda orang-orang yang beriman adalah kenyataan bahwa kezhaliman umat manusia dan tindakan mereka yang merusak pada suatu saat kelak akan berakibat pada hancurnya bumi beserta isinya.

\section{E. Penutup}

Berdasar uraian di atas maka disimpulkan bahwa masalah pelestarian lingkungan hidup terungkap dalam beberapa hadis sebagai perintah bagi manusia agar menjaga dan atau memelihara lingkungan mereka dengan baik (ihsān). Unsur-unsur lingkungan hidup yang ditunjuk oleh hadis adalah; fauna, flora, tanah, air, dan udara. Upaya-upaya yang harus ditempuh dalam melestarikan lingkungan hidup adalah antara lain; memelihara dan melindungi hewan; menanam pohon dan penghijauan; menghidupkan lahan mati; memanfaatkan udara dan air dengan baik, serta yang terpenting adalah bagaimana agar keseimbangan alam/ lingkungan dan habitat dijaga dan berupaya mengindari untuk merusaknya.

Al-Qur'an sebagai hudan li al-nas sudah barang tentu, bukan hanya petunjuk dalam arti metafisis-eskatologis, tetapi juga menyangkut masalah-masalah praktis kehidupan manusia di alam dunia sekarang ini, termasuk di dalamnya, patokan-patokan dasar tentang bagaimana manusia menyantuni alam semesta dan melestarikan lingkungan sekitarnya. Oleh karena itu, energi pada setiap makhluk hidup dibutuhkan oleh makhluk hidup yang lain, yang menyebabkan terjadinya kelangsungan hidup. Dalam Islam

55 Ibid., h. 108 
saling keterkaitan ini merupakan salah satu tujuan penciptaan Allah. Sebab Allah menciptakan sesuatu dengan tidak sia-sia.

Berdasar pada rumusan kesimpula di atas, maka dapat diimplikasikan bahwa persepsi hadis tentang pelestarian lingkungan merupakan isyarat tentang adanya keteraturan yang harus dijaga oleh setiap makhluk hidup dalam satu sistem, dan apabila sistem itu terganggu menyebabkan porak-porandanya makhluk hidup yang kokoh dan tergantung pada ekosistem.

\section{DAFTAR PUSTAKA}

Al- Qur'an al-Karim

Abdillah, Mujiono,Agama Ramah Lingkungan Perspektif Al-Qur'an,Cet.l;Jakarta: Paramadina, 2001.

Abdullah, Amin, Falsafah Kalam di Era Pos Modernisme, Yogyakarta: Pustaka PeJalar, 2004.

Al- Baqi',Muhammad Pu'ad Abduh, Mu'jam Al-Mufahraz li Alfaz al-Qur'an al-KaRim, Indonesia:Maktabah Dahlan,t.th.

Begon, Michael John L. Herper, Colir R. Townsend, Ecology:Industrials,Populations Ani Communities, Massachu Setts: Sinaur Associates, Inc;1986.

Al-Bukhary, Abu Abdullah Bin Mughirah bin al-Bardizbat, Shahih al-Bukhari, Bairut: Dar alKutub al- Ilmiyah, 1992.

Departeme Agama RI, Al- Qur'an dan Terjemahnya, Jakarta: Proyek pengadaan KiTab Suci Al-Qur'an;1992

Departemen Pendidikan Nasional, Kamus Besar Bahasa Indonesia, Edisi III; Jakarta: Balai Pustaka,2001.

Ghasali,Bahri, Lingkungan Hidup Dalam Pemahaman Islam, Jakarta: Pedoman Ilmu Jaya, 1996.

Al-Lu'lu wa al- Marjan, Cet.l; Kairo: Dar Al- Hadis, 1997.

M. Soerjani dkk, Lingkungan Sumber Daya Alam dan kependudukan Dalam Pembangunan, Jakarta: UI Press, 1987.

Al- Maragi, Ahmad Mustapa, Tafsir al- Maragi, Mesir: Mustapa al-Babi al- Halabi, 1974. 
Munziri, Mukhtashar al- sunan, Pakistan: Maktabah al-Atsariyah,t.th.

Muslim bin al-Hajjaj, Abu Husain, Shahih Muslim, Bairut: Dar Ihya Al-Turats Al-Arabi. T.th.

Al-Naysaburi, Ali al-Hasan Ali bin Ahmad al-Wahidi, Asbab al-Nuzul, Jakarta: Dinamika Barakah Utama, t,th.

Qardhawi, Yusuf, Ri'ayah al-Biah fi Al-Syari'ah al-Islam diterjemahkan oleh Abdullah Hakam Shah dengan judul "Islam Agama Ramah Lingkungan", Cet.l; Jakarta: Pustaka Al-Kautsar, 2002.

Rahman, Fazhlul, Al-Qur'an Sumber Ilmu Pengetahuan, alih bahasa M. Arifin, Jakarta : Bineka Aksara, 1987.

Riyadi, Slamet, Ekologi Ilmu Lingkungan Dasar-Dasar dan Pengertiannya, Surabaya: Usaha Nasional, 1998.

Shihab, M. Quraish, Wawasan Al-Qur'an, Bandung : Mizan, 1996.

Al-Sijistaniy, Abu Sawud Sulayman Muhammad bin Al-Asyats, Sunan Abu Daud, Indonesia: Makbatah Dahlan, t.th.

Al-Suyuti, Jalal Al-Din, Al-Durru Al-Mantsur fi Al-Tafsir al-Ma'tsur, Bairut: Dar al-Maktab alIlmiah, $1411 \mathrm{H} / 1990 \mathrm{M}$.

Yunus Muhammad, kamus Arab Indonesia, Jakarta: Hidakarya Agung, 1990. 